\title{
EVALUATION OF ENSET CLONES AGAINST ENSET BACTERIAL WILT
}

\author{
G. WELDE-MICHAEL, K. BOBOSHA ${ }^{1}$, G. BLOMME 2 , T. ADDIS, T. MENGESHA \\ and S. MEKONNEN \\ Southern Agricultural Research Institute (SARI), Awassa Research Center, P.O. Box 06, Awassa, Ethiopia \\ ${ }^{1}$ Armauer Hansen Research Institute. P.O. Box. 1005, Addis Ababa, Ethiopia \\ ${ }^{2}$ Bioversity International Uganda Office, P.O. Box 24384, Kampala, Uganda
}

\begin{abstract}
Enset (Ensete ventricosum Welw. Cheesman) is an important food crop for over $20 \%$ of the Ethiopian population living in the southern and southwestern parts of the country. Enset farmers commonly grow combinations of clones in fields, but each clone is grown for its specific use. A large number of enset clones collected from the Sidama, Gurage, Kembata Tembaro and Hadyia zones were assessed for resistance/tolerance to enset bacterial wilt, Xanthomonas campestris pv. musacearum $(\mathrm{Xcm})$ at the Awassa Agricultural Research Center, Awassa in Ethiopia, during the period 1994 to 2000. In addition, some enset clones that were reported by farmers and researchers as tolerant to $X \mathrm{~cm}$ were evaluated during the same period. The objective of the study was to screen field-grown enset clones collected from different zones of southern Ethiopia, for reaction against the wilt. All $\mathrm{Xcm}$ inoculated enset clones in each of the experiments developed disease symptoms to various intensity levels during the first 45 days after inoculation. However, several enset clones showed relative tolerance to the disease. The enset clones 'Astara', 'Buffare', 'Geziwet 2', 'Gulumo' and 'Kullo' showed 100\% disease symptoms at 30 days after inoculation and could, hence, be used as susceptible checks in future screening trials. Disease symptoms were observed on 'Mezya', 'Hiniba', 'Sorpie' and 'Sigezasarum', between 21 and 75 days after inoculation. However, some plants resumed normal growth at 90 days after inoculation. The enset clones that showed a resistant and/or tolerant reaction to the wilt pathogen should be further evaluated against a large number of $X \mathrm{~cm}$ isolates under greenhouse and field conditions.
\end{abstract}

Key Words: Ensete, resistance, susceptibility, ventricosum, Xanthomonas campestris pv. musacearum

\section{RÉSUMÉ}

Enset (Ensete ventricosum Welw. Cheesman) est une importante récolte de nourriture pour plus de $20 \%$ de la population éthiopienne qui habite dans le Sud et les parties du Sud-Ouest du pays. Les agriculteurs d'Enset dévéloppent ordinairement des combinaisons de clones dans les champs, mais chaque clone sont grandis pour son usage spécifique. Plusieurs clones d'enset recueilli du Sidama, Gurage, Kembata Tembaro et les zones de Hadyia ont été évalué pour la résistance tolérance à enset bactérien flanche, Xanthomonas campestris pv. Musacearum $(\mathrm{Xcm})$ à l'Awassa le Centre de Recherche Agricole, Awassa dans Ethiopie, pendant la période 1994 à 2000. Par ailleurs, quelque enset clone cela ont été rapporté par les agriculteurs et les chercheurs comme tolérant à Xcm ont été évalué pendant la même période. L'objectif de l'étude était de trier les clones d'enset champ-grandis recueillis des zones différentes du sud d'Ethiopie, pour la réaction contre le flanche. Tout $X c m$ a vacciné les clones d'enset dans chacune des expériences ont développé les symptômes de maladie aux divers niveaux d'intensité pendant le premier 45 jours après l'inoculation. Cependant, plusieurs enset clone la tolérance relative montrée à la maladie. L'enset clone " Astara », « Buffare », ‘ Geziwet 2 , « Gulumo » et « Kullo » ont montré $100 \%$ symptômes de maladie à 30 jours après l'inoculation et peut, donc, est utilisé comme les contrôles susceptibles dans avenir trier les procès. Les symptômes de maladie ont été observés sur " Mezya ", « Hiniba », « Sorpie » et « Sigezasarum », entre 21 et 75 jours après l'inoculation. Cependant, quelques plantes ont repris la croissance normale à 90 jours après l'inoculation. L'enset clone a montré la réaction tolérante à un et/ou résistant au flanche le pathogène devrait être plus évalué contre plusieurs $X c m$ isole sous les conditions de serre et champ.

Mots Clés: La résistance, la susceptibilité, ventricosum, Xanthomonas campestris pv. musacearum 
G. WELDE-MICHAEL et al.

\section{INTRODUCTION}

Enset (Ensete ventricosum (Welw.) Cheesman) is a monocarpic, herbaceous plant belonging to the Musacea family and the genus Ensete. Wild $E$. ventricosum is common and widespread in Ethiopia and along the rift valley in eastern Africa, all the way south to Mozambique (Simmonds, 1958). However, it is only in Ethiopia that enset has been domesticated and is cultivated for food, animal feed and fiber (Bezuneh et al., 1967). The cultivation of enset is concentrated in the southern and southwestern part of Ethiopia (Bezuneh and Feleke, 1966). There are over 200 enset vernacular names in Ethiopia (Tabogie and Diro, 1994, Addis, 2005). However, a particular clone may have different names in different geographic or language areas, while different clones could have same name (Tabogie, 1997). Tsegaye (2002) also mentioned that differences in names could be related to differences in the utilisation of a clone and the change in vernacular name after an enset germplasm exchange between communities.

Enset plantations are found at altitudes between 1,200 to 3,100 meters above sea level (Huffnagel, 1961). Most enset growing areas have an average annual rainfall of 1,100 to $1,500 \mathrm{~mm}$, a mean temperature of $10-21^{\circ} \mathrm{C}$ and a relative humidity of $63-80 \%$. The ideal soils for enset cultivation are moderately acidic to alkaline $(\mathrm{pH}$ of 5.6 to 7.3) (Bezuneh and Feleke, 1966). The area of enset cultivation in Ethiopia is estimated at over 168,000 ha (CSA, 1997). Enset is the main source of food for over 12 million people (Belhu, 1991). The average annual yield of 'Kocho' (a non-dehydrated fermented product from mixtures of decorticated pseudostems and pulverized corms) is $10.3 \mathrm{t}$ per hectare (Bezuneh and Feleke, 1966; Tabogie and Diro, 1994). Enset fiber accounts for more than $30 \%$ of the Ethiopian fiber production and its strength is equivalent to the fiber of Abaca (Brandt et al., 1997). Fresh enset plant parts are fed to livestock and some enset clones are reported to have medicinal value to humans and domestic animals (Bezuneh et al., 1967). Enset plantations prevent soil erosion and conserve soils, hence, contributing to the sustainability of the farming system (WeldeTensaye, 1997). Enset is considered as a security food crop as it can withstand long periods of drought, heavy rains, and flooding, which normally devastates other crops (Degu and Workayehu, 1990).

The sustainability of enset agriculture is, however, threatened by a number of factors including population pressure, which is associated with more intense cultivation, degradation of the soil and the environment (Quimio and Tessera, 1996). Different types of diseases,. fungal, bacterial and viral, are also affecting enset production. Bacterial wilt of enset, which is caused by Xanthomonas campestris pv. musacearum $(\mathrm{Xcm})$ is the most important disease affecting yield (Yirgou and Bradbury, 1968; Wondimagegne, 1981; Ashagari, 1985; Quimio, 1992; Quimio and Tessera, 1996; Welde-Michael, 2000).

Variable levels of clonal response against the $X \mathrm{~cm}$ disease have been observed under farmer's field conditions and while using artificial inoculation in on station trials (Anita et al., 1996; Welde Michael, 2000). Control measures which could prevent, reduce or eliminate the spread of $X \mathrm{~cm}$ in enset fields include the disinfection/ flaming of enset cutting tools after use on infected plants, preventing animals from browsing infected plants, fencing infected sites and the rigorous removal of infected plants (including the corms) (Quimio and Tessera, 1990).

The mechanical nature of $\mathrm{Xcm}$ transmission and the manner by which enset is propagated, raised and managed in a subsistence farming system, suggest that the wilt may be difficult to eradicate unless strict control options are implemented. Therefore, the use of resistant/ tolerant enset clones could offer a good approach to the control of bacterial wilt of enset (Ashagari, 1985; Quimio, 1992). Hence, studies were undertaken to evaluate large numbers of fieldestablished enset clones for their reaction against enset bacterial wilt.

\section{MATERIALS AND METHODS}

\section{Assessing enset clones from the Gurage,} Hadyia, Kembata Tembaro and Sidama zones. A total of 103 enset clones were assessed under field conditions for their reaction to enset bacterial wilt using artificial inoculation. Fourty one clones 
were collected from Gurage, 48 from Sidama, and 12 tolerant clones from the Hadyia and Kembata Tembaro zones. These 12 tolerant clones were selected from an initial 69 clones, which had been screened against $\mathrm{Xcm}$ during the period 1994-
1995 (Anonymous, 1996). In addition, the enset clones 'Mezya' and ‘Arkya' were included (Table 1).

The trail was established at the Southern Agricultural Research Institute (SARI), Awassa

TABLE 1. Plants for the different enset clones developing disease symptoms after artificial inoculation with $X \mathrm{~cm}$

\begin{tabular}{|c|c|c|c|c|c|c|c|c|c|c|c|}
\hline \multirow[t]{3}{*}{ Clone name } & \multirow[t]{3}{*}{ Collection site } & \multirow{3}{*}{$\begin{array}{l}\text { Number } \\
\text { of } \\
\text { inoculated } \\
\text { plants }\end{array}$} & \multicolumn{9}{|c|}{ Days after inoculation } \\
\hline & & & \multirow[b]{2}{*}{$7^{c}$} & - - & 一 & \multicolumn{3}{|c|}{$\%$ infected plants } & \multirow[b]{2}{*}{75} & \multirow[b]{2}{*}{90} & \multirow[b]{2}{*}{120} \\
\hline & & & & 15 & 21 & 30 & 45 & 60 & & & \\
\hline Ado & Sidama & 9 & 0 & 0 & 55 & 66 & 66 & 66 & 77 & 77 & 77 \\
\hline Astara & Sidama & 9 & 0 & 0 & 18 & 100 & 100 & 100 & 100 & 100 & 100 \\
\hline Buacho & Sidama & 9 & 0 & 22 & 44 & 44 & 100 & 66 & 66 & 77 & 44 \\
\hline Buffare & Sidama & 9 & 22 & 55 & 55 & 100 & 100 & 100 & 100 & 100 & 100 \\
\hline Genticha & Sidama & 9 & 0 & 0 & 55 & 77 & 88 & 88 & 88 & 88 & 88 \\
\hline Gulumo & Sidama & 9 & 22 & 55 & 55 & 100 & 100 & 100 & 100 & 100 & 100 \\
\hline Kullo & Sidama & 9 & 33 & 33 & 88 & 100 & 100 & 100 & 100 & 100 & 100 \\
\hline Serena (2) & Sidama & 9 & 0 & 0 & 44 & 44 & 44 & 44 & 44 & 44 & 44 \\
\hline Wonigoro & Sidama & 9 & 0 & 0 & 0 & 33 & 55 & 55 & 55 & 88 & 55 \\
\hline Achana & Gurage & 9 & 0 & 0 & 0 & 44 & 77 & 77 & 88 & 88 & 44 \\
\hline Anikefye & Gurage & 9 & 0 & 0 & 0 & 22 & 22 & 33 & 33 & 33 & 33 \\
\hline Astara & Gurage & 9 & 0 & 0 & 0 & 22 & 44 & 44 & 44 & 44 & 44 \\
\hline Bazeriet & Gurage & 9 & 0 & 0 & 11 & 44 & 55 & 33 & 11 & 11 & 11 \\
\hline Dere & Gurage & 9 & 0 & 0 & 0 & 33 & 44 & 44 & 44 & 44 & 11 \\
\hline Eminiye & Gurage & 9 & 0 & 0 & 11 & 55 & 77 & 77 & 66 & 88 & 33 \\
\hline Geziwet 2 & Gurage & 9 & 0 & 11 & 77 & 100 & 100 & 100 & 100 & 100 & 100 \\
\hline Lemat & Gurage & 9 & 0 & 0 & 0 & 33 & 33 & 22 & 22 & 22 & 22 \\
\hline Nechwe (1) & Gurage & 9 & 0 & 0 & 0 & 0 & 22 & 22 & 22 & 11 & 11 \\
\hline Weka & Gurage & 9 & 0 & 0 & 0 & 22 & 33 & 33 & 44 & 88 & 44 \\
\hline Yeshirafre & Gurage & 9 & 0 & 0 & 11 & 55 & 77 & 77 & 44 & 44 & 44 \\
\hline Hiniba & Hadyia & 24 & 0 & 0 & 33 & 50 & 50 & 50 & 50 & 33 & 33 \\
\hline Kassiet & Hadyia & 24 & 0 & 0 & 17 & 50 & 83 & 83 & 67 & 67 & 67 \\
\hline Sigezasarum & Hadyia & 24 & 0 & 0 & 33 & 50 & 67 & 50 & 50 & 50 & 50 \\
\hline Sokide & Hadyia & 24 & 0 & 0 & 33 & 50 & 50 & 50 & 50 & 50 & 50 \\
\hline Sorpie & Hadyia & 24 & 0 & 0 & 17 & 50 & 50 & 50 & 50 & 33 & 33 \\
\hline Abata merza & Kembata Tembaro & 24 & 0 & 0 & 17 & 50 & 50 & 67 & 67 & 67 & 67 \\
\hline Abate & Kembata Tembaro & 24 & 0 & 0 & 0 & 33 & 33 & 33 & 33 & 33 & 33 \\
\hline Astara & Kembata Tembaro & 24 & 0 & 0 & 17 & 50 & 50 & 67 & 67 & 67 & 50 \\
\hline Fugatessa & Kembata Tembaro & 24 & 0 & 0 & 0 & 17 & 67 & 50 & 50 & 50 & 50 \\
\hline Gishera & Kembata Tembaro & 24 & 0 & 0 & 0 & 50 & 50 & 50 & 50 & 50 & 50 \\
\hline Heila & Kembata Tembaro & 24 & 0 & 0 & 0 & 50 & 33 & 33 & 33 & 33 & 33 \\
\hline Kembate & Kembata Tembaro & 24 & 0 & 0 & 17 & 33 & 50 & 50 & 50 & 50 & 50 \\
\hline Mezya & Waka & 24 & 0 & 0 & 50 & 50 & 50 & 50 & 50 & 33 & 33 \\
\hline Arkya & Wolyita & 24 & 0 & 0 & 0 & 33 & 33 & 33 & 33 & 33 & 33 \\
\hline
\end{tabular}

${ }^{c}=$ Percentage infected plants 
Agricultural Research Center ( $7^{\circ} 03^{\prime} \mathrm{N}, 38^{\circ} 30^{\prime} \mathrm{E}$, 1,700 m above sea level); Awassa, Ethiopia in 1994 and the evaluations continued till 2000. The site has a mean annual rainfall of $1,046 \mathrm{~mm}$, which is uni-modal distributed and a relative humidity of 60 percent.

Plantlets of the different clones were produced at the SARI, Areka Agricultural Research Center in Ethiopia. The plantlets were uprooted after one year and transported to the Southern Agricultural Research Institute (SARI), Awassa Research Center. For each of the enset clones collected from the Gurage and Sidama zones, 10 vigorous and uniformly sized plantlets were planted in holes of $50 \mathrm{~cm}$ deep and with a diameter of $50 \mathrm{~cm}$. There were 3 replications of 3 plants and one control plant. On the other hand, 28 plantlets were planted per genotype from the Hadyia and Kembata Tembaro collections and for 'Mezya' and 'Arkya'. These plants were planted in a randomised complete block design with 4 replications. Each plot consisted of 1 row of 7 plants spaced $1.5 \mathrm{~m}$ from each other. There was a spacing of $1 \mathrm{~m}$ between rows and $1.5 \mathrm{~m}$ between plants in a row. There was one control plant in each replication.

Weeding was carried out every two months. A single application of $0.5 \mathrm{~kg}$ composted manure was applied per plant three months after planting.
The plants were not irrigated during the dry season.

One year after transplanting, plants were inoculated with $3 \mathrm{ml}$ of a 2 days old bacterial suspension with a cell concentration of $10^{8} \mathrm{cfu} /$ $\mathrm{ml}$ (adjusted to $0.3 \mathrm{OD}$ at $460 \mathrm{~nm}$ using spectrophotometer). The plants were inoculated at the base of the newly expanding central leaf petiole using a $10 \mathrm{ml}$ capacity sterile hypodermic syringe with metal needle. Numbers of live and, hence, injected plants per clone were recorded at the time of inoculation. The control plants were inoculated with the same volume of sterile distilled water. Disease assessment was done at 15, 21, 30, 45, 60, 75, 90 and 120 days after inoculation. The number of infected plants per clone at each disease assessment period was recorded.

Evaluation of previously reported tolerant/ resistant enset clones. A set of 12 enset clones reported as tolerant to enset bacterial wilt by farmers and researchers (Ashagari, 1985) (Table 2) were evaluated for reaction to the pathogen. This experiment was conducted at the Awassa Agricultural Research Center between 1998 and 2000. Thirty plants were planted per clone in a randomised complete block design with three replications of 10 plants. Again, there was one control plant in each replication. The same

TABLE 2. Percentage of plants for the different enset clones (previously reported as tolerant/resistant) developing disease symptoms after artificial inoculation with $X \mathrm{~cm}(\mathrm{n}=27)$

\begin{tabular}{|c|c|c|c|c|c|c|c|c|c|c|}
\hline \multirow[t]{2}{*}{ Clone name } & \multirow[t]{2}{*}{ Collection site } & \multicolumn{9}{|c|}{ Days after inoculation } \\
\hline & & $7^{c}$ & 15 & 21 & 30 & 45 & 60 & 75 & 90 & 120 \\
\hline YeshreKinke & Gurage & 0 & 0 & 0 & 0 & 11 & 44 & 88 & 88 & 88 \\
\hline Abate Merza & Hadyia & 0 & 0 & 0 & 22 & 33 & 55 & 77 & 77 & 77 \\
\hline Agade & Hadyia & 0 & 0 & 0 & 0 & 22 & 22 & 55 & 55 & 55 \\
\hline Disho & Hadyia & 0 & 0 & 0 & 11 & 11 & 22 & 22 & 22 & 22 \\
\hline Soskila & Hadyia & 0 & 0 & 0 & 0 & 22 & 55 & 55 & 55 & 55 \\
\hline Unjamo & Hadyia & 0 & 0 & 0 & 0 & 11 & 33 & 33 & 33 & 33 \\
\hline Kembate & Kembata & 0 & 0 & 0 & 0 & 22 & 22 & 22 & 22 & 22 \\
\hline Ado & Sidama & 0 & 0 & 0 & 22 & 22 & 22 & 22 & 22 & 22 \\
\hline Alanticho & Sidama & 0 & 0 & 22 & 22 & 22 & 22 & 52 & 52 & 52 \\
\hline Genticha & Sidama & 0 & 0 & 11 & 11 & 11 & 22 & 22 & 22 & 22 \\
\hline Hala & Wolyita & 0 & 0 & 0 & 11 & 11 & 22 & 22 & 22 & 22 \\
\hline Mezya & Wolyita & 0 & 0 & 0 & 0 & 11 & 11 & 11 & 11 & 11 \\
\hline
\end{tabular}

$c=$ Percentage infected plants 
agronomic practices as in the other experiments were applied.

Eight months after transplanting, plants were inoculated with $3 \mathrm{ml}$ of a 2 days old bacterial suspension using the same dilution and application protocol. Disease assesstment was done at $7,15,21,30,45,60,75,90$ and 120 days after inoculation.

The data collected were analysed using SPSS 12.0 for windows (SPSS, 2003).

\section{RESULTS AND DISCUSSION}

Evaluation of enset clones from the Gurage, Hadyia, Kembata Tembaro and Sidama zones. All inoculated enset clones developed disease symptoms at various intensity levels during the first 45 days after inoculation (Table 1). Disease severity rapidly increased thereafter for most clones. Out of the 89 enset clones collected from the Gurage and Sidama zones, only 13 enset clones showed a mean disease incidence of less than 50 percent. Clones Astara, Buffare, Geziwet 2, Gulumo and Kullo showed 100\% disease symptoms at 30 days after inoculation and could hence be used as susceptible checks in future $\mathrm{Xcm}$ screening trials. Some clones like Buacho and Wonigoro from the Sidama collection and Bazeriet and Dere from the Gurage collection recovered from an initial infection (Table 1). The enset clones Anikefye, Eminiye, Lemat and Nechwe (1) from the Gurage collection showed a relative tolerance to $\mathrm{Xcm}$ (Table 1). Ashagari (1985) did not report any complete resistance in a $X \mathrm{~cm}$ screening trial with 60 enset clones. However, the enset clones Ado, Kembate, Hedesso, Soskila, Genticha and Abate were reported as having a relative tolerance to the disease. Contrary to Ashagari's report, Ado and Genticha were found to be susceptible to the disease in the present study. This may have been caused by a variation in $\mathrm{Xcm}$ isolates used for inoculation. Variations among isolates were observed in preliminary laboratory and field experiments (Bobosha, 2003).

The highest disease incidence for clones from the Hadyia and Kembata Tembaro collections was observed on Abate Merza and Kassiet (Table 1). In contrast, Abate, Arkya, Heila, Mezya and Sorpie showed low infection levels, hence indicating a high degree of tolerance to the disease (Table 1). Some clones surmounted from the infection. Yellowish and wilted leaves were observed on clones Mezya, Hiniba, Sigezasarum and Sorpie between 21 and 75 days after inoculation; however, some of the infected plants resumed normal growth at 90 days after inoculation (Table 1).

Quimio and Tessera (1996) also observed that artificially inoculated 'Genticha' plants recovered from a $\mathrm{Xcm}$ infection at 12 to 16 weeks after inoculation. This apparent recovery may be explained by the un-systemic nature of the disease development after an artificial inoculation in the leaf petiole of a newly formed leaf. It could be possible that the bacteria stay confined to the leaf petiole and leaf sheath of this inoculated leaf. May be the bacteria cannot enter in the corm and hence cannot infect adjacent leaves as the vascular connection between leaves passes through the corm. This would result in the disappearance of the disease when the inoculated leaf eventually wilts and dies. None of the control plants for each of the tested enset clones showed wilt symptoms throughout the experimental period.

\section{Evaluation of previously reported tolerant/} resistant enset clones. All the evaluated enset clones developed wilt symptoms (Table 2). The first signs of infection (yellowing of the central leaf) were observed on Genticha and Alanticho at 21 days after inoculation. None of the control plants used for each of the tested enset clones showed wilt symptoms throughout the experimental period. Significant differences in disease infection rates were recorded. The highest infection rates were observed on Yeshrekinke and Abate Merza. However, Anita et al. (1996) reported clone 'Yeshrekinke' as a tolerant clone. Ado, Disho, Genticha, Hala, Kembate and Mezya showed low infection levels hence indicating a high degree of tolerance to the disease (Table 2). No recovery was observed for the clones assessed in this trial.

Previous reports had already indicated that the clones Ado, Genticha, Kembate and Mezya are tolerant to the disease (Ashagari, 1985 and Welde-Michael, 2000). Clone Soskila, previously reported as tolerant (Ashagari, 1985), was found 
to be susceptible in the present study. This may have been caused by a variation in $X \mathrm{~cm}$ inoculum across studies. In this study, only one virulent pathogenic $X c m$ isolate was used. Future studies under field and greenhouse conditions should thus assess the reaction of enset clones to a large number of $\mathrm{Xcm}$ isolates collected from different growing areas in Ethiopia. The clones with the highest disease infection rate could be used as susceptible checks during these future enset clonal $\mathrm{Xcm}$ screening studies.

\section{CONCLUSIONS}

This study shows that enset clones vary in their reaction to enset bacterial wilt. Some of the enset clones recover after initial disease symptom development. This recovery, in addition to the high labour requirements, makes farmers reluctant to apply the sanitary control measures. The clones that showed a tolerant reaction to the wilt pathogen should be further evaluated against a large number of $\mathrm{Xcm}$ isolates under field and greenhouse conditions. In addition, a concerted effort to collect and evaluate other clones is urgently needed. Also, $\mathrm{Xcm}$ variability and virulence needs to be thoroughly investigated.

\section{ACKNOWLEDGEMENTS}

The study was made possible through the financial support provided by the Ethiopian Institute of Agricultural Research (EIAR) and the Southern Agricultural Research Institute (SARI).

\section{REFERENCES}

Addis, T. 2005. Biology of enset root mealybug Cataenococcus ensete and its geographical distribution in southern Ethiopia. M.Sc. Thesis. Alemaya University of Agriculture, School of Graduate studies. Alemaya, Ethiopia. $81 \mathrm{pp}$.

Anita, S., Clifton, H., Endale, T. and Gizachew W.M. 1996. Enset Need Assessment Project Phase 1 Report. Awassa, Ethiopia.

Anonymous, 1996. Awassa Agricultural Research Center Progress Report of Plant Protection Research Division for 1995. Awassa, Ethiopia.
Ashagari, D. 1985. Studies on bacterial wilt of enset (Ensete ventricosum) and future prospects for its control. Ethiopian Journal of Agricultural Sciences 7(1): 1-14.

Belhu, T. 1991. The position of enset (Ensete ventricosum) research in Ethiopia. 29-32 pp. In proceedings of the regional advisory committee meeting. INIBAP, Regional Network for eastern Africa.

Bezuneh, T. and Feleke, A. 1966. The production and utilization of the genus Ensete in Ethiopia. Economic Botany 20 (1): 65-70.

Bezuneh, T., Feleke, A. and Bayie, R. 1967. The cultivation of the genus Ensete in Ethiopia. Soil and Crop Science Society of Florida 27:133-141.

Bobosha, K. 2003. Characterisation of Xanthomonas campestris pv. Musacearum isolates: Causal agent of enset bacterial wilt disease. M.Sc. Thesis. Addis Ababa, Ethiopia. 95pp.

Brandt, S. A., Spring, A., Hiebisch, C., Yntiso, G., Tabogie, E., Diro, M., Welde-Michael, G., Tesfaye, S., McCabe, J.T. and Shigeta, M. 1997. The Tree against Hunger: Enset-based agricultural systems in Ethiopia. American Association for Advancement of Science with Awassa Agricultural Research Center, Kyoto University center for African Areas Studies and University of Florida. Directorate for International programs 1200 New York Avenue, NW, Washington, DC 20005. 56pp.

CSA (Central Statistical Authority). 1997. Enset Sample Survey: May-June 1997. Report on survey results (private peasant holdings). CSA Statistical Bulletin no. 184. Addis Ababa, Ethiopia. 225pp.

Degu, G. and Workayehu, T. 1990. Initial results of informal survey of Areka area mixed farming zone, Wolyita Awraja. IAR working paper. Paper No.11 mimeograph. Addis Ababa, Ethiopia.

Huffnagel, H.P. 1961. Agriculture in Ethiopia. Rome, Italy.

Quimio, A. J. 1992. Annual Report of the Plant Pathologist: July 17, 1991-July 16, 1992. Enset Team Support Project. Sidamo, Gamo-Goffa Peasant Agricultural Development Program. PADEP III. Awassa Research Center, IAR. 
Quimio, A. J. and Tessera, M. 1996. Diseases of enset. In: Tsedeke A., Hiebsch, C., Brandt, S.A., Seifu G.M. (Eds.), pp. 188-203. EnsetBased Sustainable Agriculture in Ethiopia. Proceedings of the International Work shop on enset. Addis Ababa, Ethiopia, 13-20 December 1993.

Simmonds, N. W. 1958. Enset cultivation in the southern highlands of Ethiopia. Tropical Agriculture (Trinidad) 35: 302-307.

SPSS 12.0, 2003. SPSS 12.0 for windows. Release 12.0.0 (4 Sep 2003). Copyright (C) SPSS inc., 1989-2003.

Tabogie, E. 1997. Morphological Characterization of enset (Ensete ventricosum (Welw.) Cheesman) clones and the association of yield with different traits. M.Sc. Thesis. Alemaya University of Agriculture, School of Graduate studies. Alemaya, Ethiopia. 89 pp.

Tabogie, E. and Diro, M. 1994. Improvement studies on enset and sweet potato. In: Proceedings of the second national horticultural workshop of Ethiopia. Herath, E. and Desalegn, L. (Eds.), pp. 63-64. 1-3 December1992. IAR, Addis Ababa, Ethiopia.
Tsegaye, T. 2002. On indigenous production, genetic diversity and crop ecology of enset (Ensete ventricosum (Welw.) Cheesman). Doctoral thesis, Wageningen University. The Netherlands. 198 pp.

Welde-Michael, G. 2000. Variations in isolates of enset wilt pathogen (Xanthomonas campestris pv. musacearum) and reaction of enset (Ensete ventricosum (Welw.) clones to this disease. M.Sc. Thesis. Alemaya University, Ethiopia. 61pp.

Welde-Tensaye, A. 1997. The Ecology and Production of Ensete ventricosum in Ethiopia. Doctoral thesis, Swedish University of Agriculture Science, Uppsala. 129pp.

Wondimagegne, E. 1981. The role of Poeicilocarda nigrinervis, Pentanolia nigronervosa and Plantococcus ficus in the transmission of enset wilt pathogen Xanthomonas musacearum sp. n. in Wolayta, Ethiopia. M.Sc Thesis, Addis Ababa University.

Yirgou, D. and Bradbury, J.F. 1968. Bacterial wilt of enset (Ensete ventricosum L.) incited by Xanthomonas musacearum sp.n. Phytopathology 58: 111-112. 